\title{
Human-Crocodile Conflicts in Sarawak, Malaysian Borneo: An analysis of crocodile attacks from 2000 until 2020
}

\author{
Mohd Izwan Zulaini Abdul Gani ${ }^{1,2}$, Ruhana Hassan ${ }^{1}$, Oswald Braken Tisen ${ }^{2}$, Rambli Ahmad ${ }^{2}$ \\ ${ }^{1}$ Faculty of Resource Science and Technology, Universiti Malaysia Sarawak, \\ 94300 Kota Samarahan, Sarawak, Malaysia \\ ${ }^{2}$ Sarawak Forestry Corporation, \\ Lot 218, KCLD, Jalan Tapang, Kota Sentosa, \\ 93250 Kuching, Sarawak, Malaysia
}

Received: June 8, 2021. Revised: December 23, 2021. Accepted: January 17, 2022. Published: January 27, 2022

\begin{abstract}
Crocodiles have caused a relatively high number of fatalities towards local people in Sarawak, a Malaysian state in Borneo. However, they have important cultural values and are well respected by the riverine communities in the state. The objective of this study is to determine the patterns of human-crocodile conflict in Sarawak which could help in managing the problems between crocodile and human. Information on crocodile attacks were collected from multiple sources including records kept by local authority, media or CrocBITE database. Over a 21 years period (year 2000-2020), the record attacks $(n=164)$ showed a balance between fatal and non-fatal cases. Most common victims in Sarawak were male $(86.6 \%)$ and adults from the age of 31 to 40 years old $(20.7 \%)$. The attacks occurred more during the daylight

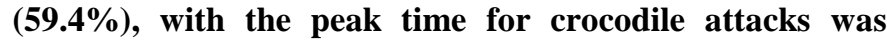
approximately between 1800 to 2359 hours (33.3\%). Crocodile attacks occur slightly more during the wet season, from October to March (54.0\%), with the highest one recorded in March (16.8\%). Fishing (26.2\%) and bathing $(22.0 \%)$ in the rivers possess the highest risk of crocodile attack, suggesting that crocodiles are more likely to attack when the victim is in the water. The findings imply that crocodiles' attack pattern in Sarawak is associated with the people's activities pattern. There is a need to update the database on crocodile attacks in Sarawak on -real time basis as this will facilitate the relevant agencies in formulating the strategies to reduce the number of crocodile attacks and ensuring the safety of the riverine communities.
\end{abstract}

Keywords- Human-crocodile conflict, attack records, mitigation.

\section{INTRODUCTION}

$\mathrm{M}$ ALAYSIA consists of three regions, the peninsular region and the two states namely Sabah and Sarawak which are located in the island of Borneo. Crocodiles in Peninsular Malaysia can be found in various areas, particularly in Rembau-Linggi Estuary and Setui-Chalok-Bari River Basin (RB) [1],[2]. Meanwhile in Sabah, crocodiles inhabit Kinabatangan River Basin and its associated wetland [3], Klias River [4], Segama River [5] and Kawang River [6].

Sarawak supports the largest population of crocodiles in Malaysia. The saltwater crocodile (Crocodylus porosus) can be found in all major river basins in Sarawak including large river systems, mangroves, estuaries and inland freshwater swamps [7]. This species also can be found in non-tidal freshwater sections in the upper region of the rivers, several hundred kilometers from sea [8]. The Malayan Gharials (Tomistoma schlegellii) also can be found in Sarawak, but they are difficult to sight in the wild. There are reports stating that this species can be found in the upper tributaries of Sadong River, Samarahan River, Baram River, Logan Bunut Lake and a few other peat swamp areas [8],[9].

Crocodiles have been long living in rivers of Sarawak and this can be proven by the presence of 'Baya Tanah', crocodile's effigies that can be found in several locations across the state including in Engkilili, Kanowit and Kapit. The earthen crocodile replicas are believed to be about 50 to 200 years old [10]. This "Baya Tanah" played an important role in the lives of native Iban farmers in the past, who held 'mali umai' ceremony (ritual at paddy farms) either in October or November each year. The main purpose for the construction of the "Baya Tanah" is to protect the paddy farms against pests, rodents and locusts. Crocodiles are regarded as special animals by the Ibans, especially for those who are still practicing traditional beliefs. It is believed that the spirit of crocodile will rise and devour all the pests in the paddy field after the "mali 
umai' ceremony and the Ibans are not allowed to leave their longhouse for three nights as the spirit will harm them [10].

Sarawak is among the fast developing states in Malaysia and the human population are also continues to increase. As a result, more people need a place to live and human settlements started to expand including in the areas near the river. As the number of people lives near the river, the conflicts between human and crocodiles (HCC) are likely to happen. At the same time, the crocodile population in Sarawak, which was once on the brink of extinction due to overexploitation, has been successfully recovered and their numbers in the wild are showing an increasing trend [11]. Now, the local authority has to address the growing number of HCC and to come up with solutions to mitigate these incidents. In other countries and regions, HCC have been properly documented over time [12],[13],[14],[15],[16],[17]. However in Sarawak, information on HCC is limited and not properly documented. There is a limited scientific publication that discuss on crocodile attack cases in Sarawak. [18] only discussed on selected incidents of crocodile attacks occurred in Lupar River. In addition, [19] shared simple statistics on crocodile attacks in Sarawak, which exclude important data about time, month, age group and victim's activity. Limited access to information regarding crocodile attacks is the major hurdles for conflict mitigation efforts. Therefore, in this study, the information of crocodile attacks on humans in Sarawak from the year 2000 until 2020 were collected from various sources and analysed. The objective is to determine the patterns of HCC in Sarawak which could help in providing information for formulating efficient and effective ways to tackle the problems between crocodile and human.

\section{STUDY AREA}

Sarawak is one of the two Malaysian states located in the north-western part of Borneo Island, the third largest island in the world. The state of Sarawak is neighbouring with another Malaysian state in Borneo, Sabah and borders a small nation of Brunei and an Indonesian province of Kalimantan (Fig. 1). Sarawak has an area of 124,450 square kilometers $\left(\mathrm{km}^{2}\right)$, located immediately north of the equator between latitude $0^{\circ} 0^{\prime}$ and $5^{\circ} \mathrm{N}$ and longitude $109^{\circ} 36^{\prime}$ and $115^{\circ} 40^{\prime}$. The coastal line of Sarawak stretches over $700 \mathrm{~km}$ along the northeastern coast of the island of Borneo and the inland is generally over $300 \mathrm{~m}$ above sea levels with certain areas exceeding $1,200 \mathrm{~m}$, particularly the mountainous area in central region of the Borneo that form the border between Sarawak and Kalimantan.

Sarawak has a tropical rainforest climate, with annual rainfall ranging between $3,300 \mathrm{~mm}$ near the coastland and $4,600 \mathrm{~mm}$ further inland [20]. Average temperature in Sarawak is around $26^{\circ} \mathrm{C}$, but it can vary according to location. Highland areas like Bario in north-eastern corner of Sarawak where the place lying at an altitude of about $1,100 \mathrm{~m}$ above sea level, with the temperature is slightly lower compared to other low land areas. The state experiences two monsoonal seasons, the Northeast and Southwest monsoons and two shorter periods of inter-monsoon seasons. The Northeast monsoon (NEM) is more prominent because of the sudden surge in the rainfall amounts, which typically occurs from months of November until March. Meanwhile, the Southwest monsoon (SWM) extending from April to September is on the contrary associated with a relatively dry period and less rainy days during the active monsoon months. The inter-monsoon periods occur during the transition between the two monsoon seasons, and it usually happens in April and October respectively [20]. Despite the monsoon seasons, the climate in Sarawak remains fairly stable with rain occurrence throughout the year.

As the largest state in Malaysia, Sarawak has a vast area of waterways, comprising of 22 major river basins that originating from the highland in the centre of Borneo and flow across the state into the South China Sea (Fig. 1). Out of all river basins in Sarawak, two river basins have a distance more than $500 \mathrm{~km}$ in length including Rajang River which is the longest river in Malaysia with its length approximately 760 $\mathrm{km}$. Another important river basins in Sarawak are Samarahan, Sadong, Lupar, Saribas, Baram and Limbang. There are also a large number of tributaries, mangrove and peat swamp areas that are linked to the major river basins throughout Sarawak such as Kuching wetland and Belawai mangroves delta.

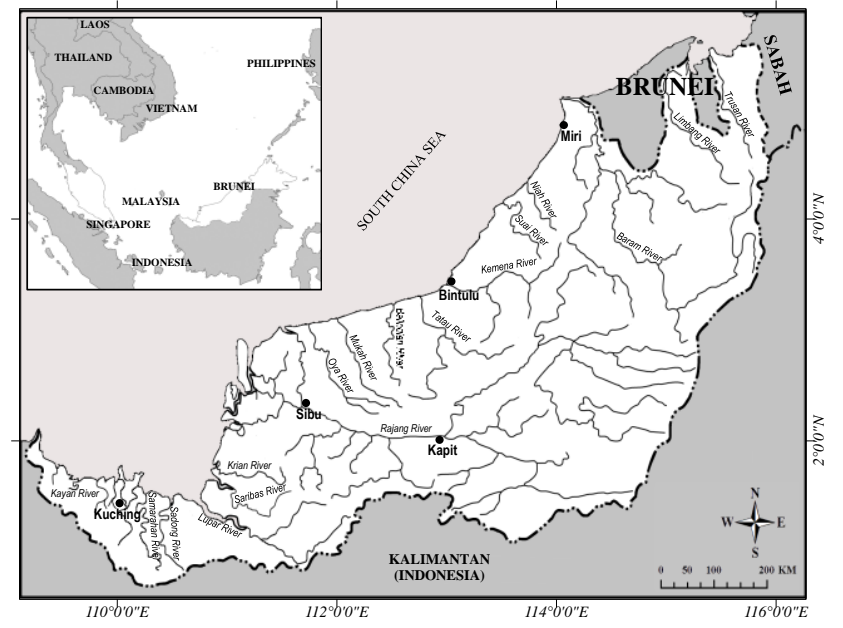

Fig. 1 Map showing major rivers in Sarawak.

\section{METHODS}

All information regarding crocodile attack incidents occurred from the year 2000 until 2020 were collected from several sources including from records kept by local agency, books, media like newspapers, online news and social media platform or through an online crocodile attack database known as CrocBITE (http://www.crocodile-attack.info). The CrocBITE is an online database of recording attacks by crocodilians on humans worldwide, developed by researchers from Charles Darwin University. New cases of crocodile attacks are being added to the database by contributors, mostly the officials or researchers from the countries or regions where the attacks occurred. 
All incidents of crocodile attacks reported in Sarawak from year 2000 until 2020 were compiled into a database created in Microsoft Excel. The details of the victims were collected when available including their sex, age, activity of victim during the incident, time of attack, and the outcome from the attack incidents (fatal or non-fatal). Geographical information such as the location and the name of the river basin where the incident happened as well as the month when the attack occurred were determined from the sources. Information on the tide in the river when the incident occurred were collected from the sources, but if the information was absent the tide was estimated from the Sarawak tide tables (2000 to 2020) based on the time and locations of the attacks. Information about the moon phase on the date of the incidents were also collected from website (https://www.timeanddate.com/moon/malaysia/kuching) and the Sarawak tide table. The moon phase was defined as four moon phases of seven-day period blocks. For instance, a `new moon' phase was defined as the period from three days prior to the new moon to three days after the new moon. A similar seven-day block was used for the full moon, first and third (last) quarter of the moon. All the incidents were considered unprovoked attacks and only the attacks confirmed caused by the crocodile were included in this analysis.

Minitab 17 (Minitab Inc., USA) and OriginPro 9.0 (OriginLab Corporation, USA) were used in this study for statistical analyses and preparation of figures based on the attack data. The trend of the crocodile attacks in Sarawak from 2000 until 2020 were examined by fitting linear regression to the number of attacks for each year [21]. Chi-square tests of independence $\left(\chi^{2}\right)$ were applied to see whether moon phase and tidal cycle had influence on frequency of crocodile attacks in Sarawak using Minitab 17 (Minitab Inc., USA).

\section{RESULTS}

From 2000 to 2020, a total of 164 cases of crocodile attack on human reported in Sarawak, with an average of 7.8 cases per year. The number of crocodile attack cases for each year per annual period showed a marked increase (regression analysis, $\left.\mathrm{DF}=1, \mathrm{p}=0.001[\mathrm{p}<0.05], \mathrm{R}^{2}=44.7 \%, \mathrm{~F}=15.37\right)$ especially between the year 2003 and 2015 (Fig. 2). A slightly more than half or $52.4 \%$ of the attack cases claimed the life of the victims, while another $47.6 \%$ of the victims survived through the attacks. The frequency of male became the victims to crocodiles is higher with $86.6 \%$ when compared to female which recorded only $13.4 \%$ from the total number of crocodile attack cases.

Adults from the age of 31 to 40 years old were the most common victims to crocodile attacks with $20.7 \%$, followed by adults from the age of 41 to 50 years old (16.5\%) (Fig. 3). Meanwhile, kids from the age of less than 10 years old and old people who aged more than 60 years old were the least common victims to crocodile attack with $5.5 \%$ and $6.1 \%$ of total number of cases, respectively (Fig. 3). Information on age of victims for $17.1 \%$ or 28 cases of the attacks is not available.

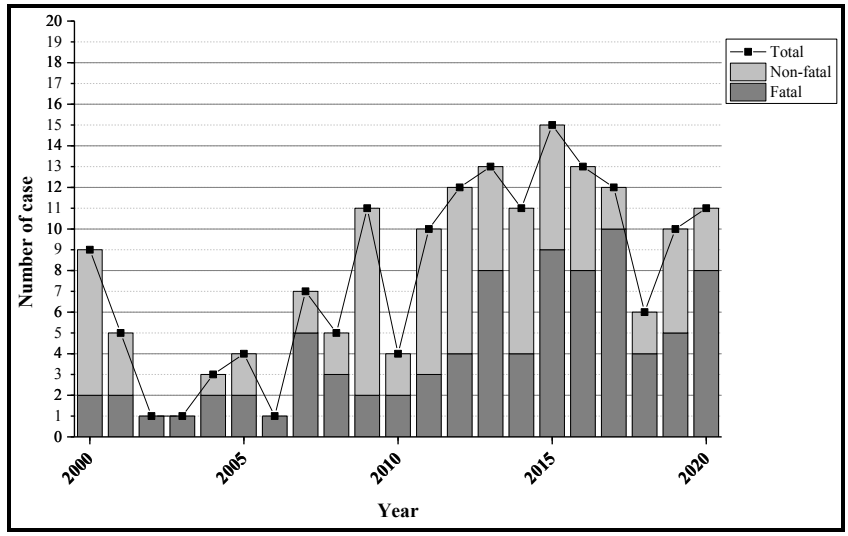

Fig. 2 Number of crocodile attacks in Sarawak for each year from 2000 until 2020.

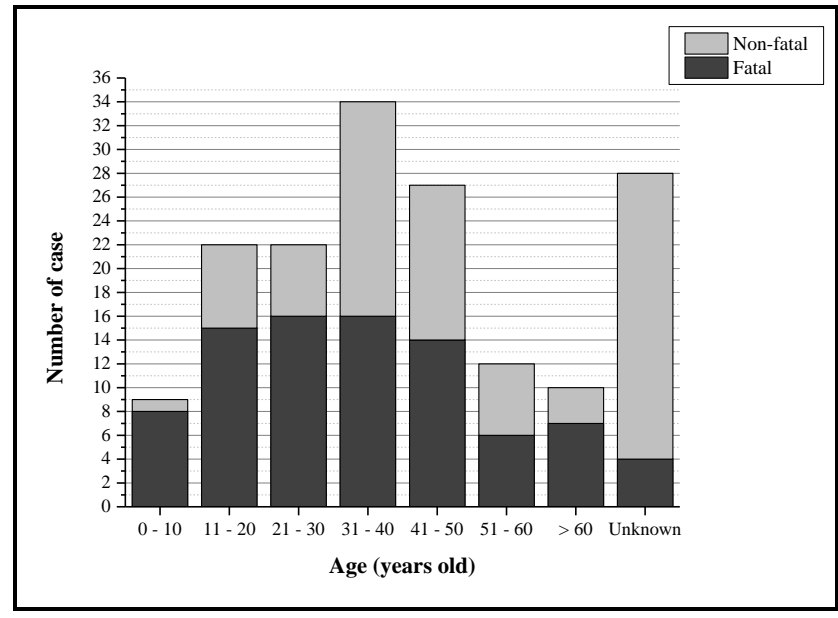

Fig. 3 Number of fatal and non-fatal attacks according to age of victims.

Crocodile attacks in Sarawak from 2000 until 2020 happened more in daylight (59.4\%) compared to night $(40.6 \%)$. However, further analysis shows that the highest proportion of the attacks happened in the late evening to midnight, between 1800 to 2359 hours $(6.00-11.59 \mathrm{pm})$ with $33.3 \%$, closely followed the time period between 1200 to 1959 hours $(12.00-5.59 \mathrm{pm})$ whereas $31.9 \%$ of attacks were taking place in that period of time. Almost $25.5 \%$ of attacks occurred in the morning from 0600 to 1159 hours $(6.00-11.59 \mathrm{am})$, while crocodile attacks were rarely occurred between midnight to early morning, 0000 to 0559 hours $(12.00-5.59 \mathrm{am})$ with only $7.3 \%$ (Fig. 4) 


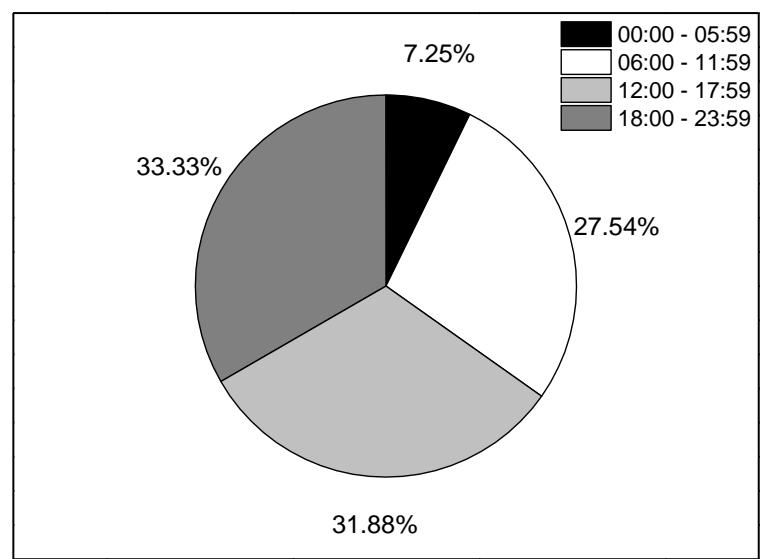

Fig. 4 Frequency of crocodile attack according to time period when the incident occurred.

There is no significant relationship on the frequency of attacks caused by crocodiles with the moon phase $(\chi 2=1.225$, $\mathrm{df}=3, \mathrm{p}=0.747[\mathrm{p}>0.05])$. Out of 56 incidents occurred at night, more attacks were reported during the first quarter of the lunar cycle with $32.1 \%$ (Fig. 5). Attacks that occur during full moon were the second highest with $26.8 \%$, followed by the new moon $(25.0 \%)$ and the least crocodile attacks happened in the third quarter of the lunar cycle with $16.1 \%$.

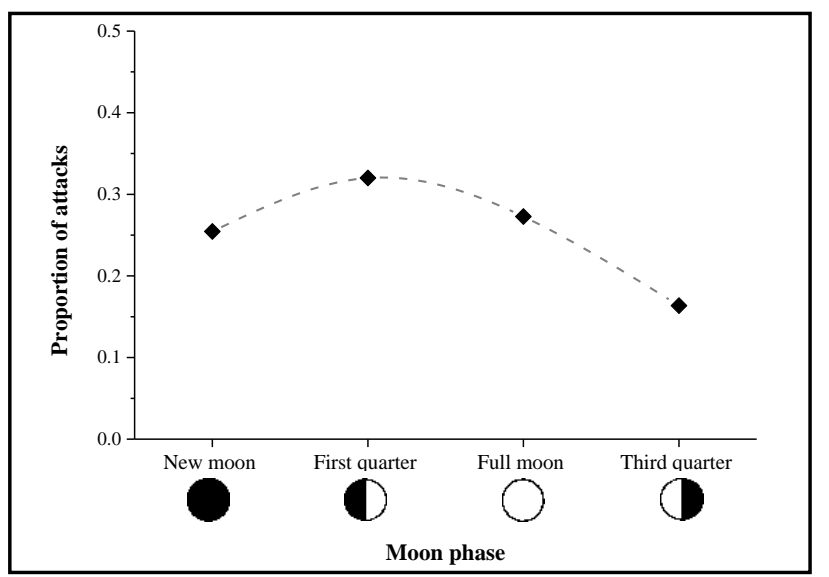

Fig. 5 Proportion of the crocodile attacks in Sarawak between 2000 and 2020 plotted over the lunar cycle.

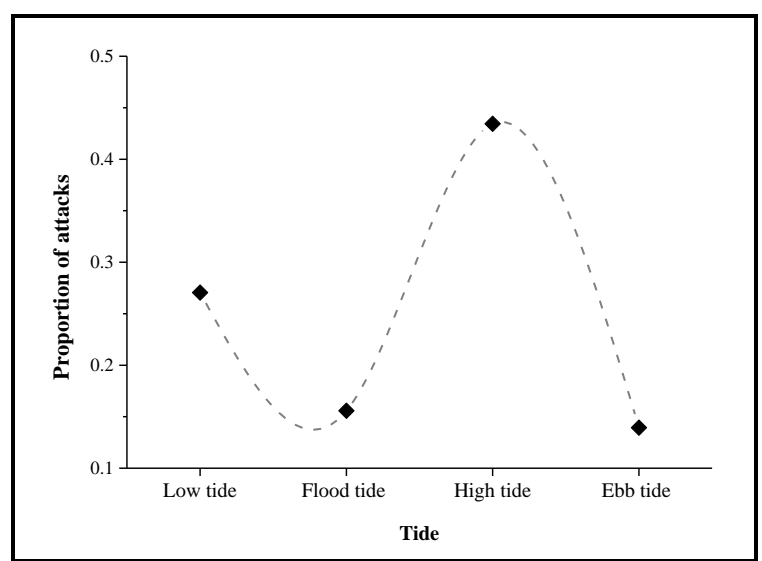

Fig 6 Proportion of the crocodile attacks in Sarawak between 2000 and 2020 plotted over the tidal cycle.
River tidal seems to have no influence on the frequency of crocodile attacks on people in Sarawak as there is no significant relationship between the two variables $(\chi 2=2.567$, $\mathrm{df}=3, \mathrm{p}=0.463[\mathrm{p}>0.05])$. Majority of attacks occurred when the tide in the river was high with $43.4 \%$ of the total number of crocodile attacks reported in Sarawak from 2000 until 2020 (Fig. 6). Then, it was followed by low tide where $27.0 \%$ of crocodile attacks occurred in that period. Flood tide, the reverse flow, occurring during rising tides from low to high tide and ebb tide, the period between high and low tide during which water flows away from the shore were the third highest and the last with $15.6 \%$ and $13.9 \%$, respectively.

From 2000 until 2020, crocodile attacks occurred in 20 out of 22 major river basins (RB) in Sarawak. The highest crocodile attacks were recorded in the Lupar RB with 31 cases (18.9\%) from the total number of cases, followed by the Saribas RB and Samarahan RB with 20 cases (12.2\%) and 17 cases (10.4\%), respectively. The Miri River basin (RB), Limbang RB and Trusan RB recorded the lowest cases of crocodile attack with only one case $(0.6 \%)$ for each river basin. No attack was recorded in Balingian RB and Mukah RB (Fig 7).

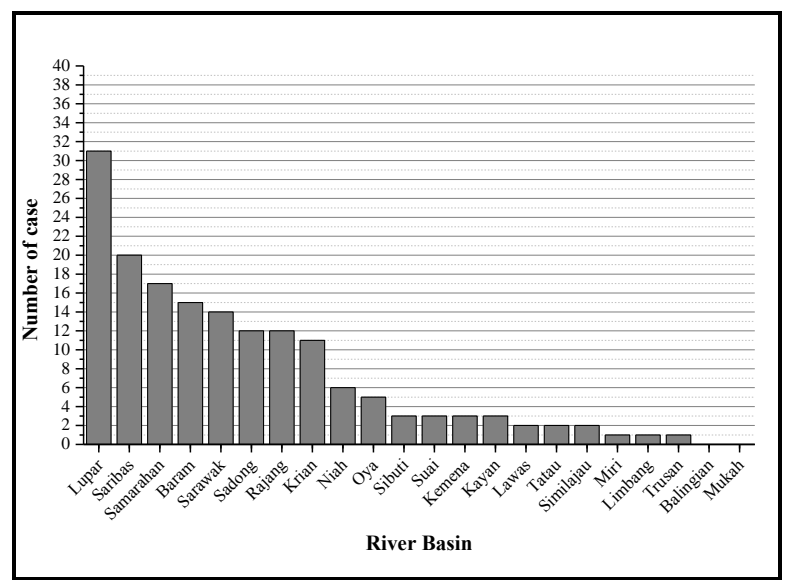

Fig 7 Number of crocodile attacks from 2000 - 2020 according to river basin.

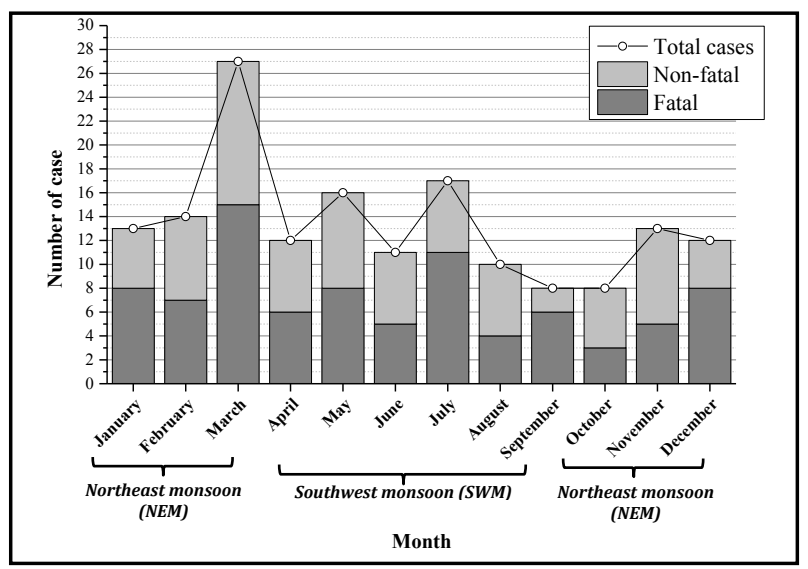

Fig 8 Number of crocodile attacks from 2000-2020 according to month and season when the incident occurred.

The peak month for a crocodile attack in Sarawak from 
2000 to 2020 was in March with 27 cases (16.8\%). The number of attacks in July was the second highest with 17 cases (10.6\%), followed by May (16 cases, 9.9\%). October and September recorded the lowest number of attacks with only 8 cases or $5.0 \%$ (Fig. 8). Meanwhile in terms of monsoon season, the attack occurred slightly higher during the NEM (October to March), with $54.0 \%$ of the total number of cases, while another $46.0 \%$ of crocodile attacks occurred during the SWM (April to September).

Table I: Number crocodile attacks in Sarawak from 2000 2020 according to the types of activities of the victims at the moment of crocodile attacked.

\begin{tabular}{|c|c|c|c|c|}
\hline & \multirow[t]{2}{*}{ Location / activity } & \multicolumn{2}{|c|}{ Number of attacks } & \multirow[t]{2}{*}{ Total } \\
\hline & & Fatal & Non-fatal & \\
\hline \multirow[t]{5}{*}{1} & In water / water's edge & & & \\
\hline & Bathing / Defecating & 20 & 16 & 36 \\
\hline & $\begin{array}{l}\text { Swimming / } \\
\text { wadding / crossing } \\
\text { stream }\end{array}$ & 4 & 5 & 9 \\
\hline & $\begin{array}{l}\text { Washing / } \\
\text { performing ablutions }\end{array}$ & 7 & 6 & 13 \\
\hline & fishing & 27 & 16 & 43 \\
\hline 2 & \multicolumn{4}{|c|}{ At riverbank, landing stage, jetty, road } \\
\hline & Working & 14 & 9 & 23 \\
\hline & Walking & 0 & 1 & 1 \\
\hline & Playing / resting & 2 & 0 & 2 \\
\hline \multirow[t]{4}{*}{3} & On boat, canoes & & & \\
\hline & $\begin{array}{l}\text { Crocodile grab } \\
\text { victim from boat }\end{array}$ & 7 & 5 & 12 \\
\hline & $\begin{array}{l}\text { Victim slip into } \\
\text { water and then } \\
\text { attack by crocodile }\end{array}$ & 1 & 0 & 1 \\
\hline & $\begin{array}{l}\text { Boat overturn / } \\
\text { collide due to attack } \\
\text { by crocodile }\end{array}$ & 1 & 0 & 1 \\
\hline 4 & Unknown activity & 3 & 20 & 23 \\
\hline & Total & 86 & 78 & 164 \\
\hline
\end{tabular}

The most common case of crocodile attacks in Sarawak from 2000 until 2020 occurred while the victims were fishing with $26.2 \%$ from the total attacks, followed by bathing or defecating $(22.0 \%)$ and working at the riverbank (14.0\%) (Table I). Besides that, crocodile attacks were also occurred while the victims were washing or performing ablutions (wudu') $(7.9 \%)$, crocodile grab victim from boat $(7.3 \%)$, swimming or wading in the river $(5.5 \%)$ and playing or resting at the riverbank or at the jetty (1.2\%). Meanwhile, victims slipped into the water from the boat, their boat overturned or collided and crocodile attack while walking at the riverbank had recorded the least incidents, with only one case or $0.6 \%$. Incomplete information about the activities of the victim when the crocodile attack comprised $14.0 \%$ of the cases (Table 1).

\section{DISCUSSION}

Detailed information on crocodile attacks in Sarawak prior to year 2000 were limited, due to lack of proper records collected by the authority on this matter. The incident of crocodile attack always become hot issue in Sarawak. When an attack happens, the news will spread fast to the other people in the state through media, consequently leading to the rising concern and fear especially among the riverine community. However, there were some crocodile attack incidents that were unreported or not known to many people especially in the remote areas due to lack of connectivity and communications. With the development of information and communication technologies (ICT), communications are easier and more effective. Thus, reports or information on crocodile attacks can be received faster and more accurately, compared to more than 20 or 30 years ago. New cases of crocodile attacks in Sarawak can be reported instantly and the public could be aware about the incidents on the same day. Every known details of the attack incidents can be recorded in the database and the information can be used for research purposes. Cases of crocodile attacks in the state also had been added to CrocBITE, an online database of recording attacks by crocodilians on humans worldwide.

Crocodile populations in Sarawak are on the road of recovery after being seriously depleted in 1980's due to intensive hunting and overkilling [22]. Law introduced to protect the crocodile from hunting combined with a series of conservation programs has been successful in helping the animal to recover. Recent surveys on the crocodile population throughout Sarawak by local agencies showed a marked increase in crocodile density in several rivers and it was estimated that the number of crocodiles living in rivers in Sarawak was around 13000 individuals [11],[23],[24].

However, the successful recovery of the crocodile population in Sarawak came with a cost as the increasing number of crocodiles in the river contributed to the increasing frequency of encounters with the human which could lead to conflict between human and crocodile. The average of crocodile attacks in Sarawak from 2000 to 2020 (7.8 cases/year) is higher compared to the nearby countries or regions such as Timor Leste with the average attacks of 6.4 cases/year in between year 2007 until 2014 [17] and Queensland, Australia with average 0.8 cases/year [14]. In addition, the average number of attacks in Sarawak is also not far less when compared to Sundarban, India where the average attacks recorded 9.1 cases/year in 2000 until 2013 [15].

Among the two species of crocodiles that can be found in Sarawak, the saltwater crocodile, Crocodylus porosus was responsible for almost all the attacks reported in Sarawak. This species of crocodile is mostly feared by local peoples in Sarawak especially the riverine communities because of its vicious nature [25] and many people have fallen victim to these reptiles. The fatality rate associated with crocodile attack in Sarawak $(51.1 \%)$ is considered high compared to nearby countries or regions. In Queensland, Australia, 34.3\% of attacks by crocodiles since 1971 have been fatal [14], while a fatality rate of $48.8 \%$ have been reported in Indonesia from 
2000 until 2014 [13]. In comparison, a relatively high fatality rate was recorded in Surdarban, India with $62.2 \%$ of attacks [15] and $82.2 \%$ for Timor Leste [17]. Meanwhile in other parts of the world, fatality rates of $60.0 \%$ caused by saltwater crocodile and $51.0 \%$ caused by mugger crocodile have been recorded in South Asia and Iran [26]. In Mozambique, mortality rates of $79.0 \%$ were observed among people attacked by crocodiles [27].

More male victims involved in crocodile attacks in Sarawak compared to females, most likely be attributed to the prevalence of specified gender roles within the community in Sarawak with the occupation or activities related to water bodies. Occupations or activities like fishing, collecting shrimp and crab during low tide and collecting plants or woods (e.g., rumbia, sago) at the riverbank in Sarawak are mostly dominated by men. Conversely in Sundarban, India where tiger prawn and crab collections are among the important activities, there were fewer male victims of crocodile attack than females. This is because in Sundarban, more women than men are involved in the collection of tiger prawn and crabs [15].

Similar reasons could explain why higher proportions of attacks in Sarawak were involving adult persons (age between 31 to 40 years old, $19.3 \%$ and age between 41 to 50 years old, $16.3 \%$ ), which are also likely to be attributed to the occupation or activities. Adults, especially in the riverine communities typically take the responsibility to find income and food for their families, mostly with river-related activities for example fishing using active and passive techniques. Eight out of nine cases (Fig. 3) of crocodile attacks involving children below 10 years old resulted in death to the victim. This showed how vulnerable this age group was when they were attacked by the crocodile. Children are usually unaware about the danger they will face when they come near the water body and when they are attacked by crocodiles, they are powerless to escape even with a small crocodile [28]. Responsible agencies in Sarawak had started an awareness campaign called " 3 M Buaya" aiming to educate children on crocodiles. 3M stands for "Mengenali, Memahami and Memulihara" which means to Know, Understand and Conserve while 'Buaya' is the Malay word for crocodile [19]. Although attacks still happen to children, it shows some improvement in the awareness among the children and parents about the risk of crocodile attack and the importance of safety measures when doing activities near the river.

Crocodile attacks in Sarawak from 2000 to 2020 occurred more in daylight compared to at night. The timing of attacks seems to be associated with human activity patterns. Local people in Sarawak are more likely to use the river for daily chores, travel or working during daylight [29]. Further analysis shows that the highest proportion of the attacks happened in late evening to midnight, between 1800 to 2359 hours $(6.00-11.59 \mathrm{pm})$ (Fig. 4). Although most of the activities are done during the day, some people prefer to do activities like bathing or washing tools in the river at dusk or night. Certain activities such as fishing and collecting mangrove crabs could also be carried out during night. At night, humans are more vulnerable to crocodiles and risk of attacks are greater compared to daylight as crocodiles could hardly be seen by human naked eyes in the dark. On the other hand, crocodiles are nocturnal animals, and they actively hunt prey at night [3],[30],[31], hence contributing to the attack on humans. In addition, the crocodile has advantages in the dark situation as they possess a relatively large lens, a retina and a tapetum lucidum in its eyes which enhance vision in dim light environments [32].

Several studies have found that the lunar cycle and the availability of moonlight has an influence on wildlife activity and conflicts with humans, especially when it involves nocturnal predators like lion and cheetah or large herbivores like elephants [16],[33],[34],[35]. In the present study, there is no significant relationship on the frequency of attacks caused by crocodiles with the moon phase where more attacks were reported during the first quarter of the lunar cycle (Fig. 5). Therefore, there is not enough evidence to suggest that the lunar cycle had influence on the frequency of crocodile attack on humans in Sarawak. Other nocturnal predators like lion and cheetah in Africa were found to be more aggressive leading to more attacks on humans during the dark nights following the full moon [33],[35]. However, these terrestrial animals have a better chance of encountering humans compared to crocodiles. Crocodile encounters with humans only happen when humans go down to the river or do activities in the riverbank. It is not known whether the lunar cycle influences the usage of rivers by people in Sarawak, but for activities like fishing, some fishermen or anglers like to fish on the days when sunrise or sunset and moonrise or moonset coincide with new or full moon phases. It is believed that during that period, combined with good river conditions, the chance for the fishermen to get a good fishing catch will increase [36].

River tidal seems to have no influence on the frequency of crocodile attacks on people in Sarawak as there is no significant relationship between the two variables. Although the statistical analysis showed a lack of significant influence of river tides on frequency of attacks, a high proportion of attacks occurred during high tide indicating high risk of crocodile attack during the period. River will be flooded with water during high tide allowing the reptile to travel further to areas near to humans. During the spring tides, the water level becomes exceptionally high and the phenomenon which is also known as "king tide" when collided with heavy rain in monsoon season could lead to flooding in lowland areas [20]. During the flood, crocodiles could swim closer to people's houses and potentially attack them. There have been reports of crocodile attacks occurring during the flood including an incident in 2016 where a man was attacked by a crocodile while removing woods under his house during flood. High frequency of attacks during high tide could also be associated with the behaviour of crocodiles. A study by [37] suggested that crocodiles prefer to stay near riverbanks during high tides or incoming tides, therefore, increase the possibility of crocodiles encountering humans. Furthermore, crocodiles are at an advantage when water level is high as the animals could easily approach victims unnoticed, especially those who are 
doing activities in the water edge or at riverbank, before the crocodiles launch a sneak attack on the victims [38]. During low tide, activities like knee-deep fishing in shallow water and collecting foods or materials in the riverbanks are common for people in Sarawak, therefore they could face danger of attacks by crocodiles when doing those activities. The reptile could be lurking near to the victims waiting to attack or when walking along the riverbank, they could bump into crocodiles while the animals are resting or possibly guarding their nest.

Always referred to as the 'Land of many rivers', 22 river systems in Sarawak have been providing a vast habitat area for crocodiles. The presence of crocodile attacks on people in 20 out of 22 river systems in Sarawak between 2000 and 2020 suggest the distribution of the reptile throughout the state. The Lupar River recorded the highest attacks among all the river systems in Sarawak. Crocodile attacks in the Lupar River are not something rare as the crocodile had been long terrorizing communities who live near the river even before the year 2000. Not less than 26 persons had been killed by crocodiles in the Lupar River and several more were injured in attacks between the year 1940 to 2000 [25]. The infamous huge crocodile called 'Bujang Senang' was thought to be responsible for numerous attacks in the river and the 19 feet 3 inches white-backed crocodile was shot dead in 1992 after it killed a woman.

Several authors have reported that crocodile attacks were more frequent in warmer months [14],[38]. However in Sarawak, crocodile attacks are distributed throughout the year, with slightly more attacks occurring in wet season compared to dry season. The peak month of crocodile attacks was in March, which coincided with the end of the wet season in Sarawak. Similarly, in Indonesia, more crocodile attacks tend to happen at the end of the wet season [13]. [39] suggested several explanations for the marked seasonality of attack by crocodile which could be used to explain the pattern of attacks in Sarawak. During the wet season, there are more rainy days causing an increase in water level and more areas were flooded allowing crocodiles to be widely dispersed. At the same time, fishing activities increased during this season due to the abundance of prawn [18], thus more people are using the rivers, consequently, increasing potential encounters between human and crocodile, whereby in some unfortunate circumstances, crocodile attacks occur. In addition, the breeding season for crocodiles typically coincides with the wet season and crocodiles are usually more dangerous at this time. Crocodiles in Sarawak usually start to mate at the end of the dry season and females build their nest in the wet season [18]. Adult males tend to move around and fighting often occurs in pursuit of breeding partners, while females can become aggressive in defense of their nest or and hatchling [30],[38], [40].

Meanwhile, during the dry season people are using rivers more frequently for the purpose of bathing or washing clothes and tools. In some areas in Sarawak, where the tap water is not available or in limited supply, people are still depending on rainwater as source of drinking water and water from rivers for other domestic use [29]. Furthermore, hot temperature and less rainy days during the dry season also draws more people to do recreational activities like swimming and boating in the waterways, bringing them into closer proximity with the crocodiles. Two cases have been reported in 2012 involving crocodile attacks in a public recreational beach near Santubong, Kuching.

Activities like fishing and bathing / defecating possess the highest risk of crocodile attack in Sarawak. Fishermen frequently use cast net (jala) as the methods of fishing and they are commonly thrown the cast net in wrist or knee-deep water during the low tide, exposing themselves to the crocodile attack. High percentage of attacks involving fishermen is a major concern as this indicates that there is still lack of awareness among them about safety precautions and the danger they are facing especially for those who are fishing in the waist or knee deep water. In some rural areas in Sarawak, Bathing, defecating or washing in the river are common for local people who live near the river as it is the main source of water for them as their areas may have not been supplied with clean pipe water yet. Based on data by [41], as of 2017, it is estimated that $81 \%$ of the area in Sarawak has been supplied with treated water through a pipeline system while the rest of the area is not yet connected with the system. Meanwhile, lack of proper bathing and toilet facilities provided by some of the plantation owners to their workers also contributed to the crocodile attacks. In between 2000 to 2020 , there are at least 12 cases of plantation workers attacked by crocodiles while working, bathing, washing cloths and defecating in the waterways in plantation areas or near their dormitory were reported in Sarawak.

The data also clearly show that activities in water or near water's have greater risk of crocodile attacks (combine all activities, $64.6 \%$, ) compared to the ones on the land. The majority of crocodile attack incidents in other countries like Australia, Indonesia, Timor-Leste, India and Sri Lanka were also occurred when the victims were in the middle of doing water-bound activities like bathing, washing and fishing [12],[13],[15],[17],[21]. In water, humans are vulnerable to an attack by crocodiles as the reptiles are capable to swim or submerge underwater and sneak near the victim undetected before they launch an attack [38]. In a number of reports, victims were having no idea of the presence of a crocodile near them before the attack. Attacks on people in boats and sampan are of particular interest. Although the number is less compared to fishing and bathing, but it has concerned a lot of people as it could indicate that travelling by boat is unsafe. Many people are worried that the crocodiles who are responsible for attacking people in boats will repeat the behaviour and strike again. Typically, large and aggressive crocodiles are the one who are responsible for attacking people on boats as they are capable to overturn boats or leap out of water and grab victims from boats [38].

Gathering information on crocodile attack is essential as this information can be used for identifying potential risks and hotspot areas for attacks. With this information, outreach programs should be focused appropriately for demographic groups; for example, among attacks in Sarawak, most of 
victims were attacked while fishing, particularly in wrist and knee-deep water, thus awareness programs should be involving more fishermen and also people who do fishing regularly as a hobby. Furthermore, attacks data and case study of local attacks should be shared especially with communities who live in hotspot areas of crocodile attack, so that they can become more alert when they are using the waterways. Educating children should be a priority and this can be done through attractive awareness programs. The programs also need to involve parents so that they can learn to monitor their children's activities for safety reasons. The opportunity to prevent further attacks could help in mitigating human crocodile conflict in Sarawak and the most important thing is saving many lives [39].

\section{CONCLUSION}

Several important information had been learned from attacks data in Sarawak between 2000 to 2020, which could help in finding formulas to minimize risk of attacks toward local people. From the study, findings indicated that either men or women, adults or children, all were potentially to become victims of crocodile attacks. Attacks more often happened in the wet season, particularly in March and the peak time for crocodile attacks was in between late evening to midnight, from 6 to $12 \mathrm{pm}$. Crocodile attacks had occurred in 20 out of 22 river basins in Sarawak with the highest number of attacks recorded in the Lupar River. It is clear that reliance on water bodies for activities such as fishing, bathing and washing is key to reduction of human - crocodile conflicts in Sarawak. Database on crocodile attacks in Sarawak is recommended to be updated on an on-going basis as this will facilitate the identification of emerging trends and hotspot areas. There is also a need to have a comprehensive study on the size of crocodile populations in Sarawak as well as their seasonal behaviour and movement together with the environmental event (drought, floods) and anthropogenic intervention (pollution, river development, land use), in which affect the distribution of crocodiles in the state.

\section{ACKNOWLEDGMENT}

The authors would like to thank Sarawak Forestry Corporation for providing access to records of crocodile attacks kept by the agency. Special appreciation to CrocBITE database administrators and contributors especially cases involving attacks in Sarawak. The authors would also like to express gratitude to the Universiti Malaysia Sarawak (UNIMAS) for the small fund, Ph.D. Grant no. F07/DPP53/1282/2015(28).

\section{REFERENCES}

[1] Nazli, M. F., Hashim, N. R., \& Zakaria, M. (2009). Distribution, Abundance and Habitat Conservation of Crocodylus porosus in Rembau-Linggi Estuary, Peninsular Malaysia. Pp 130-135. In Postgraduate Qolloquium First Semester 2009/2010. Selangor, Malaysia: Universiti Putra Malaysia.
[2] Webb, G. J. W., Manolis, C., \& Brien, M. L. (2010). Saltwater Crocodile, Crocodylus porosus. In C. Manolis \& C. Stevenson (Eds.), Crocodile. Status Survey and Conservation Action Plan. Third Edition (pp. 99-113). Darwin: Crocodile Specialist Group.

[3] Evans, L. J., Davies, A. B., Goossens, B., \& Asner, G. P. (2017). Riparian Vegetation Structure and the Hunting Behavior of Adult Estuarine Crocodiles. PLOS ONE, 12(10), 1-12.

[4] Stuebing, R., Ismail, G., \& Ching, L. H. (1994). The Distribution and Abundance of the Indo-Pacific Crocodile Crocodylus porosus Schneider in the Klias River, Sabah, East Malaysia. Biological Conservation, 69, 1-7.

[5] Kaur, T. (2006). Segama River Survey. Crocodile Specialist Group Newsletter, 25(1), 14-15.

[6] Jet, O., Palaniappan, P. M., \& Hussein, M. A. S. (2011). Population Ecology and Potential Food Sources of The Saltwater Crocodiles in Kawang River, Sabah. Borneo Science, 28, 57-65.

[7] Hassan, R., Md Adzhar, M. A. A., Abdul-Gani, M. I. Z., \& Ahmad, R. (2018). Assessment of Wild Saltwater Crocodile Population in Bako River, Western Sarawak, Malaysian Borneo for Potential Ecotourism Industry. Malaysian Applied Biology, 47(1), 131-138.

[8] Hassan, R., Ahmad, R., Md Adzhar, M. A. A., AbdulGani, M. I. Z., Ayob, A., and Zainudin, R. (2016). Notes on the Wild Tomistoma Populations in Western Sarawak, Malaysian Borneo. International Journal of Ecology, 2016, 1-7.

[9] Stuebing, R. B., Bezuijen, M. R., Auliya, M., and Voris, H. K. (2006). The Current and Historic Distribution of Tomistoma schlegelii (the False Gharial) (Müller, 1838) (Crocodylia, Reptilia). Raffles Bulletin of Zoology, 54(1), 181-197.

[10] Datan, I., Stephen, C., and Nicholas, D. (2012). Earthen Crocodile Effigies (Buaya Tanah) of the Iban of Sarawak: A Preliminary Study. Sarawak Museum Journal (New Series), LXX (9), 145-160.

[11] Sarawak Forestry Corporation. (2018). Management Plan for Estuarine Crocodile (Crocodylus porosus) in Sarawak 2016-2020. Kuching: Sarawak Forestry Corporation.

[12] Amarasinghe, A. T., Madawala, M. B., Karunarathna, D. S., Manolis, S. C., de Silva, A., \& Sommerlad, R. (2015). Human-Crocodile Conflict and Conservation Implications of Saltwater Crocodiles Crocodylus porosus (Reptilia: Crocodylia: Crocodylidae) in Sri Lanka. Journal of Threatened Taxa, 7(5), 7111-7130.

[13] Ardiantiono, A., Sheherazade, Karta Atmadja, R., and Wardhani, A. (2015). Analisis Serangan Buaya Muara (Crocodylus porosus) di Indonesia melalui eksplorasi Database CrocBITE Berbasiskan Citizen Science (An Analysis of Saltwater Crocodile (Crocodylus porosus) Attack in Indonesia using Citizen Science CrocBITE Database Exploration). Inovasi Online, 24(3), 8-16.

[14] Brien, M. L., Gienger, C. M., Browne, C. A., Read, M. A., Joyce, M. J., and Sullivan, S. (2017). Patterns of Human-Crocodile Conflict in Queensland: A Review of Historical Estuarine Crocodile (Crocodylus porosus) Management. Wildlife Research, 44(4), 281-290. 
[15] Das, C. S., and Jana, R. (2017). Human-Crocodile Conflict in the Indian Sundarban: An Analysis of SpatioTemporal Incidences in Relation to People's Livelihood. ORYX, 2017, 1-8.

[16] Lamichhane, B. R., Persoon, G. A., Leirs, H., Poudel, S., Subedi, N., Pokheral, C. P., . . . de Iongh, H. H. (2018). Spatio-temporal Patterns of Attacks on Human and Economic Losses from Wildlife in Chitwan National Park, Nepal. PLOS ONE, 13(4), 1-18.

[17] Sideleau, B. M., Edyvane, K. S., and Britton, A. R. C. (2016). An Analysis of Recent Saltwater Crocodile (Crocodylus porosus) Attacks in Timor-Leste and Consequences for Management and Conservation. Marine and Freshwater Research, 68(5), 801-809.

[18] Stuebing, R., Ismail, G., and Kusuadi, S. (1985). The Ecology of Crocodile Attacks in Batang Lupar, Sarawak. Sarawak Museum Journal, 34, 195-215.

[19] Tisen, O., Gombek, F., Ahmad, R., \& Ubang, C. K. (2013). Human-Crocodile Issues: Sarawak Report. Pp 115. In World Crocodile Conference. Proceedings of the $22^{\text {nd }}$ Working Meeting of the IUCN-SSC Crocodile Specialist Group. Gland, Switzerland: IUCN.

[20] Sa'adi, Z., Shahid, S., Ismail, T., Chung, E.-S., \& Wang, X.-J. (2017). Distributional Changes in Rainfall and River Flow in Sarawak, Malaysia. Asia-Pacific Journal of Atmospheric Sciences, 53(4), 489-500.

[21]Fukuda, Y., Manolis, C., \& Appel, K. (2014). Management of Human-Crocodile Conflict in the Northern Territory, Australia: Review of Crocodile Attacks and Removal of Problem Crocodiles. The Journal of Wildlife Management, 78(7), 1239-1249.

[22] Cox, J. H., and Gombek, F. (1985). A preliminary survey of the crocodile resources in Sarawak, East Malaysia. Kuala Lumpur: World Wildlife Fund (WWF) Malaysia.

[23] Abdul-Gani, M. I. Z. (2019). Historical Perspective, Distribution, Ecology and Population Genetics of Saltwater Crocodile (Crocodylus porosus Schneider, 1801) in Sarawak, Malaysian Borneo. (Unpublished Doctoral dissertation). Universiti Malaysia Sarawak, Sarawak, Malaysia.

[24] Abdul-Gani, M. I. Z., and Hassan, R. (2016). Crocodile in Batang Rajang of Kanowit District, Sarawak, Malaysia. Pp 128-135. In Samsur, M., Shabdin, M.L., Nyanti, L., Khairul Adha, A.R., Hadil, R. and Mobilik, J.M. (Eds.), Aquatic Science Colloquium 2016: Experience Sharing in Aquatic Science Research IV, Malaysia Exclusive Economic Zone (EEZ) Cruise and other Aquatic Science Research. Monograph, Department of Aquatic Science, Universiti Malaysia Sarawak, Kota Samarahan, Sarawak, Malaysia.

[25] Ritchie, J., and Jong, J. (2002). Man-eating Crocodiles of Borneo. Kota Kinabalu, Sabah: Natural History Publications (Borneo).

[26] Stevenson, C., De Silva, A., Vyas, R., Nair, T., Mobaraki, A., and Aleem Chaudhry, A. (2014). Human-Crocodile Conflict in South Asia and Iran. Pp 209-226. In Crocodiles. Proceedings of the $23^{\text {rd }}$ Working Meeting of the IUCN-SSC Crocodile Specialist Group. Gland, Switzerland and Cambridge, UK: IUCN.
[27] Dunham, K. M., Ghiurghi, A., Cumbi, R., and Urbano, F. (2010). Human-wildlife Conflict in Mozambique: A National Perspective, with emphasis on Wildlife Attacks on Humans. $O R Y X, 44(2), 185-193$.

[28] Fukuda, Y., Manolis, C., Saalfeld, K., and Zuur, A. (2015). Dead or Alive? Factors Affecting the Survival of Victims during Attacks by Saltwater Crocodiles (Crocodylus porosus) in Australia. PLOS ONE, 10(5), 112.

[29] Hassan, R., and Abdul-Gani, M. I. Z. (2013). Crocodiles in Western of Sarawak, Malaysia. Pp 90-94. In World Crocodile Conference. Proceedings of the $22^{\text {nd }}$ Working Meeting of the IUCN-SSC Crocodile Specialist Group. Gland, Switzerland: IUCN.

[30] Campbell, H. A., Dwyer, R. G., Irwin, T. R., \& Franklin, C. E. (2013). Home Range Utilisation and Long-Range Movement of Estuarine Crocodiles during the Breeding and Nesting Season. PLOS ONE, 8(5), 1-9.

[31] Emerling, C. A. (2017). Archelosaurian Color Vision, Parietal Eye Loss, and the Crocodylian Nocturnal Bottleneck. Molecular Biology and Evolution, 34(3), 666676.

[32] Grigg, G. C., and Gans, C. (1993). Morphology and Physiology of the Crocodylia. In C. G. Glasby, J. Ross \& P. L. Beesley (Eds.), Fauna of Australia Vol 2A: Amphibia and Reptilia (pp. 326-336). Canberra: Australian Government Publishing Service.

[33] Cozzi, G., Broekhuis, F., McNutt, J. W., Turnbull, L. A., Macdonald, D. W., \& Schmid, B. (2012). Fear of the Dark or Dinner by Moonlight? Reduced Temporal Partitioning among Africa's Large Carnivores. Ecology, 93(12), 2590-2599.

[34] Gunn, J., Hawkins, D., Barnes, R. F. W., Mofulu, F., Grant, R. A., \& Norton, G. W. (2014). The Influence of Lunar Cycles on Crop-raiding Elephants; Evidence for Risk Avoidance. African Journal of Ecology, 52(2), 129137.

[35] Packer, C., Swanson, A., Ikanda, D., \& Kushnir, H. (2011). Fear of Darkness, the Full Moon and the Nocturnal Ecology of African Lions. PLOS ONE, 6(7), 14.

[36] Sulaiman, N. A. S. (2018). Fisherman's Knowledge of the Moon Phenomenon in Fishing Activities. International Journal of Academic Research in Business and Social Sciences, 8(11), 941-949.

[37] Mohd-Azlan, J., Zulaiha, J., Lading, E., Nuriza, A. A., \& Das, I. (2016). Employing Camera Traps for Studying Habitat Use by Crocodiles in a Mangrove Forest in Sarawak, Borneo. Herpetological Review, 47(4), 579-583.

[38] Caldicott, D. G. E., Croser, D., Manolis, C., Webb, G., and Britton, A. (2005). Crocodile Attack in Australia: An Analysis of Its Incidence and Review of the Pathology and Management of Crocodilian Attacks in General. Wilderness \& Environmental Medicine, 16(3), 143-159.

[39] Pooley, S. (2015). Using Predator Attack Data to Save Lives, Human and Crocodilian. ORYX, 49(4), 581-583.

[40] Webb, G. J. W., Manolis, S., Buckworth, R., and Sack, G. (1983). An Examination of Crocodylus porosus Nests in Two Northern Australian Freshwater Swamps, with an 
Analysis of Embryo Mortality. Wildlife Research, 10(3), 571-605.

[41] Department of Statistics Malaysia. (2017). Statistic Yearbook of Sarawak 2016. Jabatan Perangkaan Malaysia, Negeri Sarawak. Retrieved from https://newss.statistics.gov.my/newss-

portalx/ep/epDownloadContentSearch.seam?cid=131467.

\section{Contribution of Individual Authors to the Creation of a Scientific Article (Ghostwriting Policy)}

MOHD IZWAN ZULAINI ABDUL GANI designed the study, collected and analysed data, writing the article.

RUHANA HASSAN assisted in designing the study, analysing data, and writing the article.

OSWALD BRAKEN TISEN assisted in designing study, gathering and collecting data

RAMBLI AHMAD assisted in designing study, gathering and collecting data,

Sources of Funding for Research Presented in a Scientific Article or Scientific Article Itself

This research was funded by Research and Innovation Management Centre (RIMC), Universiti Malaysia Sarawak, through Ph.D. Grant no. F07/DPP53/1282/2015(28).

\section{Creative Commons Attribution License $\mathbf{4 . 0}$} (Attribution 4.0 International, CC BY 4.0)

This article is published under the terms of the Creative Commons Attribution License 4.0

https://creativecommons.org/licenses/by/4.0/deed.en_US 